\title{
Pengaruh Konsentrasi Pati dan Yeast pada Pembuatan Etanol dari Pati Sorgum Melalui Proses Simultaneous Saccharification and Fermentation (SSF) dan Separated Hydrolysis Fermentation (SHF)
}

\author{
Kristinah Haryani*, Hargono, Noer Abyor Handayani, Hendra Harles, Sheila Amanda Putri \\ Departemen Teknik Kimia, Fakultas Teknik, Universitas Diponegoro Semarang \\ Jl. Prof. Soedarto, S.H., Tembalang, Semarang, 50275, \\ Telp./Fax. (024)7460058/(024)76480675 \\ *E-mail: krisyanidelapantiga@gmail.com
}

Diterima: 22-12-2020; Direvisi: 14-07-2021; Dipublikasi: 27-08-2021

\begin{abstract}
Abstrak
Bioetanol merupakan anhydrous alkohol yang dapat diproduksi dengan cara fermentasi pati. Sorgum mengandung pati yang cukup tinggi sebesar 74,63g / 100g bahan sehingga dapat dimanfaatkan sebagai bahan baku pembuatan etanol. Pembuatan etanol berbahan baku pati sorgum ada dua metode yaitu Separated Hydrolysis Fermentation (SHF) dan Simultaneous Saccharification and Fermentation (SSF). Tujuan dari penelitian ini adalah menentukan proses yang tepat untuk memproduksi etanol dari pati sorgum dengan membandingkan metode fermentasi SSF dan SHF. Untuk masing masing proses digunakan variabel konsentrasi pati sebesar 10\%, 20\% (berat/volume) dan Saccharomyces Cereviciae sebagai yeast saat proses fermentasi sebesar 5\%, 7\%, 9\% dari berat pati. Enzim Stargen ${ }^{\mathrm{TM}}$ sebesar $1 \mathrm{ml} / 100$ gram pati sorgum digunakan untuk membantu proses hidrolisis. Dari hasil fermentasi selama 72 jam menunjukkan bahwa sorgum yang difermentasi dengan metode SSF menghasilkan lebih banyak etanol sebesar 111,944 gram/liter dibandingkan metode SHF sebesar 108,645 gram/liter dengan konsentrasi pati sebesar 20\% (berat/volume) dan yeast $9 \%$ w pati.
\end{abstract}

Kata kunci: etanol; sorgum; fermentasi; hidrolisis

\begin{abstract}
Bioethanol is an anhydrous alcohol that can be produced by fermentation of starch. Sorghum contains a fairly high starch of $74.63 \mathrm{~g} / 100 \mathrm{~g}$ of material so that it can be used as raw material for ethanol production. There are two methods of making ethanol based on sorghum starch, namely Separated Hydrolysis Fermentation (SHF) and Simultaneous Saccharification and Fermentation (SSF). The purpose of this study was to determine the appropriate process for producing ethanol from sorghum starch by comparing SSF and SHF fermentation methods. For each process used starch concentration variables of 10\%, $20 \%$ (weight/volume) and Saccharomyces Cereviciae as yeast during the fermentation process of 5\%, 7\%, 9\% of the weight of starch. Stargen ${ }^{T M}$ enzyme $1 \mathrm{ml} / 100$ gram of sorghum starch was used to assist the hydrolysis process. The results of fermentation for 72 hours showed that sorghum fermented with the SSF method produced more ethanol by 111.944 grams/liter than the SHF method of 108.645 grams/liter with a starch concentration of $20 \%$ (weight/volume) and yeast $9 \% \mathrm{w}$ starch.
\end{abstract}

Keywords: ethanol; sorghum; fermentation; hydrolysis

\section{Pendahuluan}

Bioetanol merupakan anhydrous alkohol yang berasal dari fermentasi pati. Bioetanol hadir sebagai bahan bakar alternatif yang lebih ramah lingkungan, sifatnya yang terbarukan mampu menurunkan emisi $\mathrm{CO}_{2}$ hingga $18 \%$, dibandingkan dengan emisi bahan bakar fosil [7] Tahap pembutan bioetanol dengan fermentasi cairan yang mengandung gula, baik berupa glukosa, sukrosa, maupun fruktosa dibantu oleh mikroorganisme atau fermentation agent seperti yeast atau ragi terutama Saccharomyces sp [16].

Pati atau starch merupakan polisakarida hasil sintesis dari tanaman hijau melalui proses fotosintesis. Bahan baku pembuatan pati dapat diperoleh dari biji sorgum. Sorgum mengandung karbohidrat sebesar 74,63g / 100g bahan, yang dapat diolah menjadi etanol [18] Dengan luasnya lahan penanaman sorgum yang telah ada, sangat mendukung untuk 
memanfaatkan sorgum tidak hanya sebagai bahan baku industri tepung serta pakan ternak tetapi juga dapat dijadikan bahan baku pembuatan bioetanol [8].

Penelitian ini bertujuan untuk membandingkan pembuatan bioethanol dari pati sorgum dengan cara Separated Hydrolysis Fermentation (SHF) dan Simultaneous Saccharification and Fermentation (SSF) .Pada proses SHF pati dihidrolisis dulu menggunakan enzim Stargen yg terdiri dari amilase dan glukoamilase menjadi monosakarida terutama glukosa kemudian di fermentasi menggunakan Saccharomyces Cereviciae .Pada proses SSF enzim dan Saccharomyces Cereviceae ditambahkan bersamaan sehingga proses hidrolisis dan fermentasi terjadi secara simultan [6].

Produksi etanol berbahan dasar sorgum dengan proses hidrolisis enzimatik serta fermentasi hidrolisat menggunakan enzim $\alpha$-amylase dan yeast Saccharomyces cerevisiae dengan metode $S H F$ menghasilkan etanol sebesar 0,499g/g bahan baku [3]. Penelitian lain tentang produksi bioetanol berbahan dasar sorgum dengan menggunakan enzim glukoamilase dan yeast Saccharomyces cerevisiae menghasilkan hasil maksimum etanol per gram sorgum adalah $0.1257 \mathrm{~g}$ dan 0.1332 g.[6] Beberapa peneliti telah banyak melakukan penelitian yang berhubungan dengan pembuatan bioetanol dari berbagai bahan baku. Kebaruan pada penelitian ini digunakannya enzim Stargen ${ }^{\mathrm{TM}}$ yang merupakan campuran alfa amilase dan glukoamilase dan untuk fermentasi digunakan yeast Saccharomyces Cerevisiae baik pada proses SHF maupun SSF.

\section{Material dan Metode Penelitian}

\subsection{Material}

Bahan yang digunakan dalam penelitian ini adalah tepung sorgum diperoleh dari merk dagang Mama Kamu Yoygakarta. Yeast Saccharomyces cerevisiae yang diperoleh dari Agrotekno Lab, Yogyakarta. Enzim Stargen ${ }^{\mathrm{TM}}$ yang diperoleh dari Stargen, Inc. Enzim Stargen adalah campuran enzim $\alpha$-amilase dan gluco-amilase. Glukosa, $\mathrm{KH}_{2} \mathrm{PO}_{4}$, $\mathrm{CO}\left(\mathrm{NH}_{2}\right)_{2}$, dan $\mathrm{MgSO}_{4} .7 \mathrm{H}_{2} \mathrm{O}$ yang diperoleh dari Laboratorium Teknik Kimia Universitas Diponegoro.

\subsection{Persiapan Inokulum}

Saccharomyces cerevisiae dikembangbiakan pada $300 \mathrm{ml}$ medium dengan komposisi 0,9 gr glukosa, 0,009 gr $\mathrm{KH}_{2} \mathrm{PO}_{4}, 0,009$ gr $\mathrm{MgSO}_{4} .7 \mathrm{H}_{2} \mathrm{O}, 0,009 \mathrm{~g} / \mathrm{L}$ urea. Sebelum diinokulasi medium diautoclave pada suhu $121^{\circ} \mathrm{C}$ selama 20 menit. Setelah itu medium ditambahkan yeast sebanyak $0,3 \mathrm{~g} / \mathrm{L}$, kemudian diinkubasi pada suhu $35^{\circ} \mathrm{C}$ dan $120 \mathrm{rpm}$ selama 24 jam menggunakan shaker.

\subsection{Fermentasi Separated Hydrolysis Fermentation (SHF)}

Proses fermentasi secara SHF dimulai dengan melarutkan pati dengan aquades sesuai dengan variabel yang ditentukan. Kemudian semua larutan tersebut diatur pHnya menjadi 4,2 lalu diberi buffer Natrium asetat. Larutan kemudian ditambahkan enzim Stargen ${ }^{\mathrm{TM}} 1 \mathrm{ml} / 100$ gr pati, campuran tersebut diinkubasi pada suhu ruang $\left(30^{\circ} \mathrm{C}\right)$ selama 24 jam dengan pengadukan $100 \mathrm{rpm}$. Kemudian larutan ditambahkan ragi sesuai variabel beserta nutriennya. Proses fermentasi dilakukan selama 72 jam dengan pengambilan sampel sebanyak $15 \mathrm{ml}$ setiap 24 jam dan diuji kadar etanol dan gula reduksi yang dihasilkan.

\subsection{Fermentasi Simultaneous Saccharification and Fermentation (SSF)}

Medium SSF sebanyak $600 \mathrm{ml}$ terdiri dari pati sorgum dengan konsentrasi 10\% dan 20\% (berat/volume), ditambah Na-acetat buffer ( $\mathrm{pH} 5)$, enzim stargen ${ }^{\mathrm{TM}} 1 \mathrm{ml} / 100$ gr pati [2], yeast $(5 \%, 7 \%$, dan $9 \% \mathrm{v} / \mathrm{v})$. Sampel, nutrien, dan buffer disterilisasi selama 20 menit pada autoclave. Kemudian di tambah enzim $1 \mathrm{ml} / 100 \mathrm{gr}$ pati serta yeast $(5 \%, 7 \%, 9 \%$ v/v) 
Kristinah Haryani dkk /Jurnal Rekayasa Mesin p-ISSN: 1411-6863, e-ISSN: 2540-7678

Vol.16|No.2|132-139|Agustus|2021

Fermentasi dilakukan selama 72 jam pada suhu $35^{\circ} \mathrm{C}$ pada kecepatan pengadukan 100 rpm dengan sampling sebanyak 15 ml tiap 24 jam kemudian dianalisa kadar etanol dan gula reduksi yang dihasilkan.



Gambar 1. Alur vProses Pembuatan Etanol

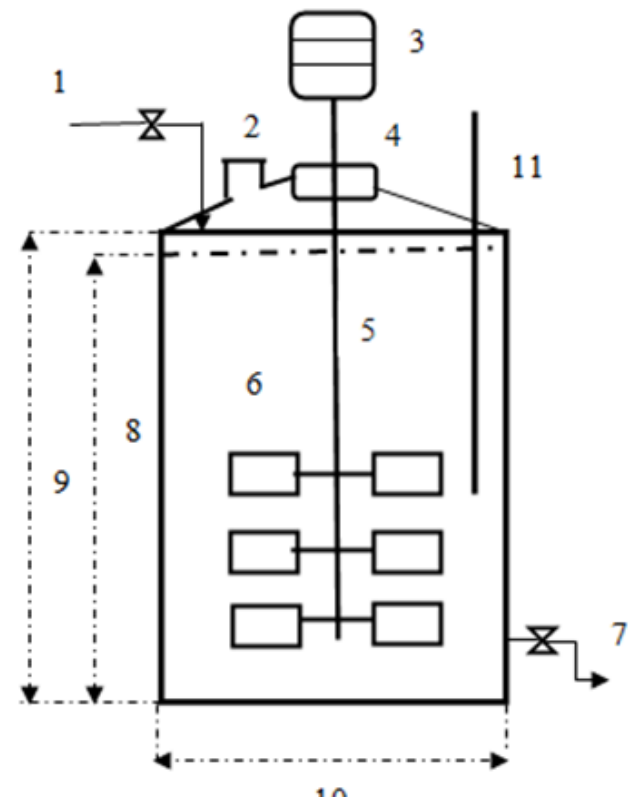

10
Keterangan gambar

1. Pipa inokulasi

2. Lubang pemasukkan substrat

3. Motor pengaduk

4. Seal stirrer shatt

5. As pengaduk

6. Impeller

7. Pipa pengambil sampel dan pipa nitrogen masuk

8. Tinggi cairan substrat

9. Tinggi fermentor

10. Diameter fermentor

11. Termometer

Gambar 2. Fermentor Tempat Pembuatan Etanol 
Kristinah Haryani dkk /Jurnal Rekayasa Mesin

p-ISSN: 1411-6863, e-ISSN: 2540-7678

Vol.16|No.2|132-139|Agustus|2021

\subsection{Analisa Kadar Gula Reduksi}

Gula reduksi dalam sampel dianalisa menggunakan metode Somogyi-Nelson. Kemudian larutan diukur absorbansinya dengan menggunakan spetrofotometer UV-Vis pada gelombang $540 \mathrm{~nm}$ dan dibandingkan dengan kurva standart.

\subsection{Uji Kadar Etanol}

Etanol hasil fermentasi dimasukkan kedalam gelas ukur $100 \mathrm{ml}$. Kemudian dimasukkan alkoholmeter ke dalam gelas ukur tersebut. Alkoholmeter akan tenggelam dan didiamkan selama 1 menit. Lalu lihat skala yang terbaca pada alkoholmeter yang menunjukkan kandungan alkohol dalam larutan.

\section{Hasil dan Pembahasan}

\subsection{Pengaruh Konsentrasi Pati dan Yeast Terhadap Kadar Gula Reduksi Sisa Hasil Fermentasi}

Pada reaksi Simultaneous Sacharification and Fermentation (SSF), polisakarida terkonversi menjadi monosakarida dan secara simultan akan difermentasi menjadi etanol. Untuk mengetahui kinerja yeast maka dilakukan fermentasi batch selama $72 \mathrm{jam}$. Analisa gula reduksi total yang tidak bereaksi dilakukan dengan metode Somogyi Nelson untuk variasi konsentrasi pati $10 \%(\mathrm{w} / \mathrm{v})$ dan 20\% (w/v) serta konsentrasi yeast sebesar 5\%, 7\% dan 9\%.



Gambar 3. Analisa Hasil Kadar Gula Reduksi pada Konsentrasi Pati 10\% (w/v)

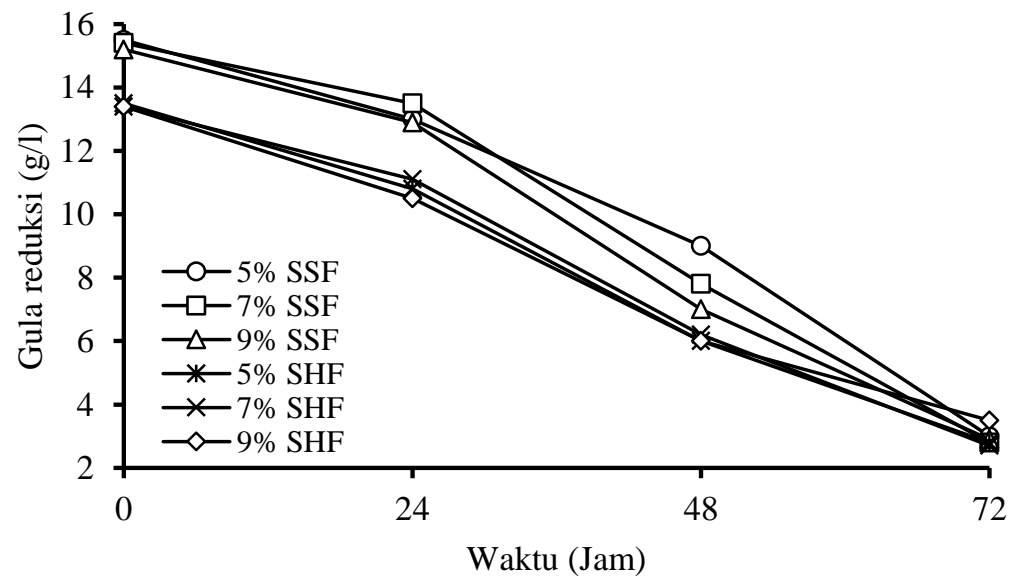

Gambar 4. Analisa Hasil Kadar Gula Reduksi pada Konsentrasi Pati 20\% (w/v) 
Gambar 3 dan gambar 4 menunjukkan bahwa untuk variabel konsentrasi pati yang sama semakin besar konsentrasi yeast maka terlihat jumlah gula reduksi yang bereaksi semakin besar. Hasil maksimum gula reduksiyang bereaksi untuk masing-masing konsentrasi pati yaitu: untuk konsentrasi pati $10 \%$ adalah 12,315 gram/liter sedangkan untuk konsentrasi pati $20 \%$ adalah 13,410 gram/liter. Semakin besar kadar konsentrasi pati dengan jumlah yeast yang sama maka reaksi berjalan semakin cepat pula sehingga kadar gula reduksi yang tersisa semakin kecil [10].

Peningkatan kadar gula reduksi yang bereaksi seiring meningkatnya konsentrasi pati disebabkan oleh meningkatnya jumlah substrat pati yang dapat dihidrolisis. Semakin banyak substrat yang ada maka semakin banyak pula ikatan yang terjadi antara enzim dan substrat [5] Interaksi antara enzim dan substrat yang semakin lama menyebabkan semakin banyak gula reduksi yang terbentuk [1]. Selanjutnya dengan bantuan saccharomyces cerevisiae menghasilkan enzim yang bisa mengubah gula reduksi menjadi etanol. Semakin banyak yeast yang digunakan maka semakin banyak mikroba yang menghasilkan enzim zimase [12] dimana enzim zimase ini mampu mengubah glukosa dan fruktosa menjadi karbondioksida dan alkohol [6] Hal ini sudah sesuai dengan hasil penelitian yang dilakukan dimana kadar gula reduksi yang dihasilkan dari proses hidrolisis digunakan dalam proses fermentasi sehingga semakin lama waktu fermentasi maka kadar glukosa yang tersisa semakin kecil. [14]

Pada penelitian yang dilakukan [13] produksi etanol dengan bahan dasar batang sorgum manis dengan metode fermentasi $S S F$ dan $S H F$ yang dilakukan pada $\mathrm{pH} 5$ dan suhu $35^{\circ} \mathrm{C}$ selama 72 jam dengan pengambilan sampel setiap 12 jam. Menggunakan Pichia Kudriavzevii sebagai yeast dalam tahap fermentasinya. Dalam penelitian [15] menunjukkan profil konsentrasi glukosa yang menurun selama fermentasi berlangsung, pada fermentasi SSF kadar glukosa pada 12 jam pertama terpantau sebanyak $22,1 \mathrm{~g} / \mathrm{l}$ dan terus menurun menjadi 15,1 pada 24 jam fermentasi berlangsung hingga menjadi $1,05 \mathrm{~g} / \mathrm{l}$ saat fermentasi telah berjalan selama $48 \mathrm{jam}$. Pada fermentasi $S H F$ kadar glukosa pada 12 jam pertama terpantau sebanyak 15,03 g/l dan terus menurun menjadi $0,71 \mathrm{~g} / \mathrm{l}$ dan habis saat fermentasi telah berlangsung selama $24 \mathrm{jam}$. Hasil penelitian oleh [14] sejalan dengan data hasil penelitian yang telah dilakukan dimana pada gambar 3 dan 4 terlihat selama fermentasi berlangsung pola konsumsi gula reduksi yang dihasilkan dari proses hidrolisis mengalami penurunan seiring dengan berjalannya waktu fermentasi [11]. Hal tersebut terjadi dikarenakan glukosa yang telah diproduksi dikonversi menjadi etanol oleh sel-sel ragi sehingga kadar gula reduksia menurun tiap waktu.

\subsection{Evaluasi Kinerja Fermentasi Etanol pada Metode $S S F$ dan $S H F$}

Dengan membandingkan kedua metode yang memiliki variabel operasi optimum masing-masing sebesar $20 \%$ konsentrasi pati dan 9\% konsentrasi yeast, maka dapat disimpulkan bahwa metode fermentasi SSF memberikan hasil yang lebih baik dibuktikan dengan jumlah kadar glukosa yang bereaksi lebih banyak dibandingkan dengan metode fermentasi $S H F$. Hal ini sesuai dengan yang dikemukakan oleh [17]) dimana yield etanol dari proses $S H F$ lebih rendah dibandingkan dengan proses $S S F$, Ini bisa terjadi karena akumulasi dari produk hidrolisis dalam proses enzimatik dapat menyebabkan inhibisi dari proses fermentasi.

Pada hasil analisa kadar etanol dengan menggunakan Alkoholmeter, dapat diketahui bahwa semakin besar konsentrasi pati dan konsentrasi yeast, maka semakin besar pula kadar etanol yang dihasilkan. Kadar etanol hasil fermentasi dengan metode SSF didapatkan lebih besar daripada kadar etanol hasil fermentasi dengan metode SHF. Kadar etanol tertinggi terdapat pada metode SSF dengan konsentrasi pati $20 \%$ dan yeast $9 \%$ yaitu sebesar 111,944 gram/liter setelah dilakukannya fermentasi selama 72 jam. 


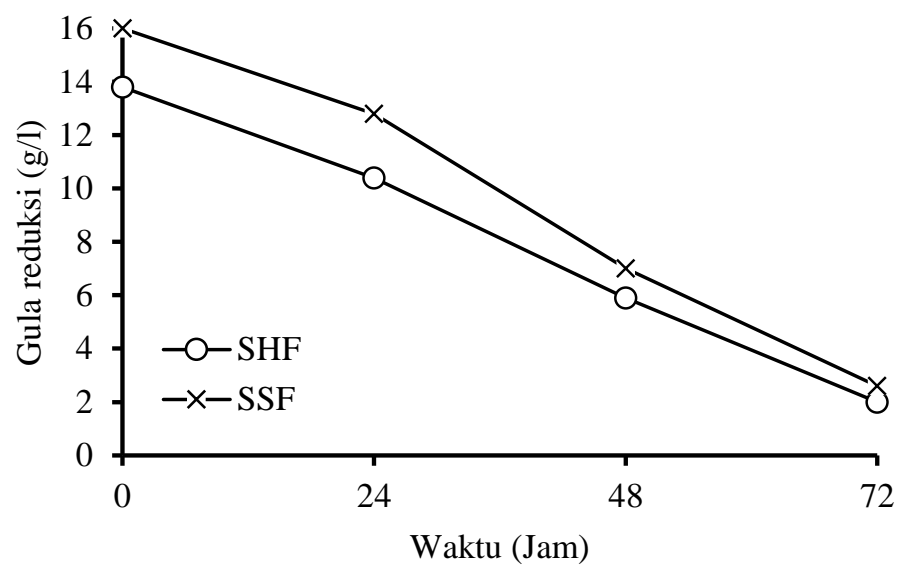

Gambar 5. Analisa Hasil Kadar Gula Reduksi pada Konsentrasi Pati 20\% dan Konsentrasi Yeast 9\%

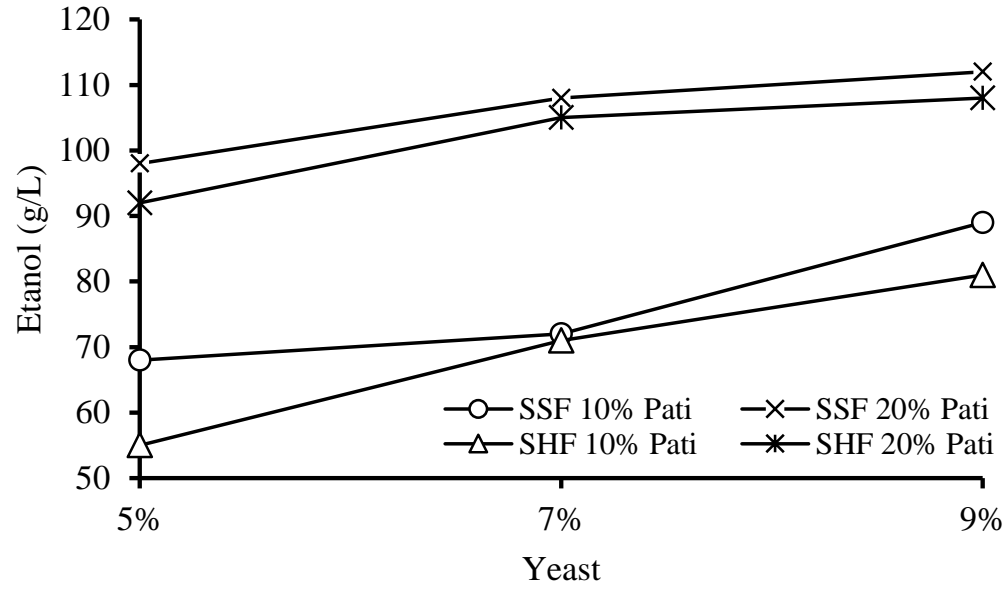

Gambar 6. Analisa Kadar Etanol Terhadap Konsentrasi Yeast

Dari gambar 6 membuktikan bahwa metode $S S F$ menghasilkan kadar etanol akhir yang lebih tinggi pada konsentrasi pati dan konsentrasi yeast yang sama. Hasil diatas dapat terjadi dikarenakan akumulasi dari produk hidrolisis dalam proses enzimatik dapat menyebabkan inhibisi dari proses fermentasi [16]. Dibandingkan dengan penelitian [8] mengenai produksi etanol dari Sorghum bicolor menggunakan metode SHF dan SSF dalam sistem batch dan fed batch, yang dilakukan pada $\mathrm{pH} 5$ dengan suhu bervariasi $30^{\circ} \mathrm{C}, 40^{\circ} \mathrm{C}, 50^{\circ} \mathrm{C}$, dan $60^{\circ} \mathrm{C}$. Menggunakan enzim cellulase dan $\beta$ glucosidase serta Saccharomyces cerevisiae Ethanol $\operatorname{Red}^{\mathrm{TM}}$ sebagai yeast dalam tahap fermentasinya. Hasil dari penelitian tersebut menunjukkan bahwa hasil fermentasi metode SSF lebih baik baik jika dibandingkan dengan fermentasi metode SHF dibuktikan dengan konsentrasi etanol hasil fermentasi SSF lebih tinggi daripada fermentasi SHF. Hasil penelitian oleh [10] sejalan dengan data hasil penelitian yang telah dilakukan bahwa etanol yang dihasilkan pada metode fermentasi SSF lebih tinggi dibandingkan dengan fermentasi SHF. Sehingga disimpulkan bahwa fermentasi SSF lebih baik karena menghasilkan produktivitas yang lebih tinggi dibandingkan dengan metode SHF [15] serta fermentasi SSF menggabungkan 2 proses yaitu sakarifikasi dan fermentasi secara bersamaan membuat capital cost dan resiko kontaminasi juga rendah [9] 
Kristinah Haryani dkk /Jurnal Rekayasa Mesin

p-ISSN: 1411-6863, e-ISSN: 2540-7678

Vol.16|No.2|132-139|Agustus|2021

\section{Kesimpulan}

Kajian mengenai produksi bioethanol berbasis sorgum menggunakan metode Simultaneous Saccharification and Fermentation (SSF) dan Simultaneous Saccharification and Fermentation (SSF) telah dilaksanakan. Hasil penelitian menunjukkan bahwa konsentrasi pati yang lebih tinggi serta konsentrasi yeast yang lebih tinggi menghasilkan etanol yang lebih banyak. Selain itu proses Simultaneous Saccharification and Fementation lebih efektif dibandingkan dengan proses Separated Hidrolysis Fermentation. Hasil yang yang relative baik diperoleh pada konsentrasi pati sorgum $20 \%$ dan konsentrasi yeast $9 \%$ dengan konsentrasi enzim Stargen ${ }^{\mathrm{TM}} 1 \mathrm{ml} / 100$ gr pati dengan proses SSF diperoleh kosentrasi etnol $111,9 \mathrm{~g} / \mathrm{l}$.

\section{Daftar Pustaka}

[1] Ambriyanto, K.S., Isolasi dan Karakterisasi Bakteri Aerob Pendegradasi Selulosa dari Serasah Daun Rumput Gajah (Pennisetum Purpureum Schaum). Surabaya; Institut Teknologi Sepuluh Nopember; 2010.

[2] Azis, Y., Ilham dan Chairul. Konversi Pati Sorgum Menjadi Bioetanol Menggunakan Variasi Konsentrasi Enzim Stargen $^{\mathrm{TM}} 002$ dan Yeast Saccharomyces Cerevisiae Dengan Proses Sakarifikasi Dan Fermentasi Serentak. Riau: Jom Fteknik 2016.Vol 3.

[3] Barcelos, C. A., Maeda, R. N., Betancur, G. J. V., \& Pereira, N., Ethanol Production From Sorghum Grains [Sorghum bicolor (L.) Moench]: Evaluation of The Enzymatic Hydrolysis And The Hydrolysate Fermentability. Brazilian Journal of Chemical Engineering. 2011.Vol. 28: p. 04.

[4] Chairul, Peratenta,M., dan Prasetyo,1.,Konversi Pati Sorgum menjadi Bioetanol menggunakan Enzim Stargent M 002 dan Yeast Saccharomyces Cerevisiae dalam Bioflo 2000 Fermentor.Riau : Skripsi Universitas Riau.

[5] Dey,P. , Rangarajan,V. , Nayak ,J. , Das ,D.B. , Wood ,S.B. An improved enzymatic pre-hydrolysis strategy for efficient bioconversion of industrial pulp and paper sludge waste to bioethanol using a semi-simultaneous saccharification and fermentation process, Fuel. 2021; p.294

[6] Dyartanti, E.R., Margono, Pranolo, S.H., Setiani, B., Nurhayati,A., Bioethanol from sorghum grain (Sorghum bicolor) with SSF reaction using biocatalyst co-immobilization method of glucoamylase and yeast, Energy Procedia. 2015; 68: hal. $132-137$

[7] Hammad, M.S.H.. Biomass Production of Saccharomyces Cerevisiae (Baker's Yeast) Using The Cactus Cladodes Extract As A Culture Medium. Gaza: Department of Biological Sciences Faculty of Science Islamic University Gaza; 2008.

[8] Hoeman, S. Riset Pengembangan Potensi Sorgum untuk Pangan, Pakan dan Energi. Batan-Bandung. 2011.

[9] Mehmood, S., Gulfraz, M., Rana, N. F., Ahmad, A., Ahring, B. K., Minhas, N., \& Malik, M. F., Ethanol Production from Sorghum Bicolor Using Both Separate And Simultaneous Saccharification and Fermentation In Batch and Fed Batch Systems. African Journal of Biotechnology. 2009; 8(12):p. 2857-2865.

[10] Nuanpeng, S. , Thanonkeo,S., Klanrit, P. , Thanonkeo ,P., Ethanol production from sweet sorghum by Saccharomyces cerevisiae DBKKUY-53 immobilized on alginate-loofah matrices ,Brazzilian Journal of Microbiology.2018;p.495

[11] Phuengjayaem, S., Teeradakorn, S., Saccharification of the acid pretreated sweet sorghum straw by Cellulase for Bioethanol Production. International Conference on Asia Agriculture and Animal IPCBEE; 2011 vol. 1, pp 1-5.

[12] Setyohadi. Proses Mikrobiologi Pangan (Proses Kerusakan dan Pengolahan. Medan: USU-Press; 2006. 
[13] Sindhu R, Binod P., Janu K.U., Sukumaran R.K., Pandey A., Organosolvent pretreatment and enzymatic hydrolysis of rice straw for the production of bioethanol. World J Microbiol Biotechnol. 2012; 28: p.473-83

[14] Szambelan, K., Nowak, J., Szwengiel, A., Jelen, H., A water-saving fermentation process for sorghum grain: The effect of re-using stillage liquid part on ethanol efficiency and volatile compounds, Journal of Cleaner Production Journal of Cleaner Production. 2020; p.265

[15] Szambelan, K., Nowak, J., Frankowski, J., Szwengiel, A., Jelen, H., Burczyk, H., The comprehensive analysis of sorghum cultivated in Poland for energy purposes: separate hydrolysis and fermentation and simultaneous saccharification and fermentation methods and their impact on bioethanol effectiveness and volatile by-products from the grain and the energy potential of sorghum straw. Bioresour. Technol. 2018; 250: p. 750-757.

[16] Triwahyunia,E., Muryanto, Sudiyani,Y., Abimanyu,H., The effect of substrate loading on simultaneous saccharification and fermentation process for bioethanol production from oil palm empty fruit bunches , Energy Procedia. 2015; 68: p.138-146.

[17] Wyman, C. E., Spindler, D. D., Grohmann, K., Simultaneous Saccharification and Fermentation For Several Lignocellulosic Feedstocks To Fuel Ethanol. Biomass and Bioenergy. 2012. Vol. 3.

[18] Zubair, A., Sorgum Tanaman Multi Manfaat. Unpad Press: Bandung. 2016 